\title{
日国際協力事業としての地すべり対策工事における事業評価法の提案 一モーリシャス共和国の例一
}

Proposal of a project evaluation method on landslide countermeasures

for international cooperation projects

-The case of the Republic of Mauritius-

桑野 健* Takeshi KUWANO / 国際航業株式会社 海外事業部防災水資源部

Disaster and Water Resources Management Division, KOKUSAI KOGYO CO., LTD

\begin{abstract}
和文要旨
近年，国際協力事業の分野で日本の地すべり対策技術は開発途上国をはじめとして広く展開されているが，多くの場合，対策工 事の事業評価を実施されるまでには至っていない。本報告ではモーリシャス共和国で日本が実施した表面排水工・水平ボーリング 工等の地すべり抑制工事の事業評価を妥当性・有効性・インパクト・効率性・持続性の観点から, 事前評価・中間評価・事後評価 の 3 段階で実施した事例を紹介する。本手法は今後の地すべり対策工事の国際協力事業においても適用可能であり，日本が技術支 援する地すべり対策を客観的に評価する上で広く利用されることが望まれる。

キーワード：地すべり，国際協力事業，事業評価，地すべり対策工事，モーリシャス
\end{abstract}

\section{1.はじめに}

日本国内に扔ける地すべり調查・解析・対策の技術は, 国土交通省をはじめとする政府機関，大学や土木研究所 等の研究機関，民間コンサルタント会社等における活動 によって日々進歩している。しかしながら, 経済が発展 中で住宅地や道路交通網が整備され始めている開発途上 の国々では，地すべりや落石，岩盤崩壊といった斜面災 害は「新たな倄威」であり，現状では対策工はほとんど 行われていないことに加えて，適切な対策を実施するた めの調查・解析技術も普及していない状況である。

「社会経済インフラの充実」を重点課題の一つとして 掲げる独立行政法人国際協力機構（以下，JICA：Japan International Cooperation Agency) では, 防災に係る プロジェクトを継続的に実施しており，従来からの河 川・海岸災害や気象災害への対策プロジェクトに加え， 特に斜面災害に対する取り組みを近年，増加させている 傾向にある (図-1 $)^{1)}$ 。特に日本政府の国際協力による 地すべり災害に係る対策工事は, 2010年以降, モーリシャ 久共和国(以下，モーリシャス) ${ }^{2)}$ ，ホンジュラス共和国 ${ }^{3)}$, エチオピア連邦民主共和国 ${ }^{4)}$ ，ネパール連邦民主共和国 ${ }^{5)}$ などで実施され，地域住民や道路利用者の地すべり災害 リスクを軽減させてきた。

こうした国際協力事業では, 援助事業の改善や説明責 任の向上を目的として，事業の実施前，実施中，実施後 にその妥当性や有効性，正負のインパクトなどを検証す ることが望ましいとされている6)。また日本国内に打い ても地すべり対策工事に対しては，技術的な概成判断の ほかに，事業によるリスク軽減に扔ける直接的・間接的 効果を判定することが主流となりつつある788。

\footnotetext{
* 連絡著者/corresponding author

厂 102-0085 東京都千代田区六番町 2 番地

Rokuban-cho 2, Chiyoda-ku, Tokyo, 102-0085, Japan
}

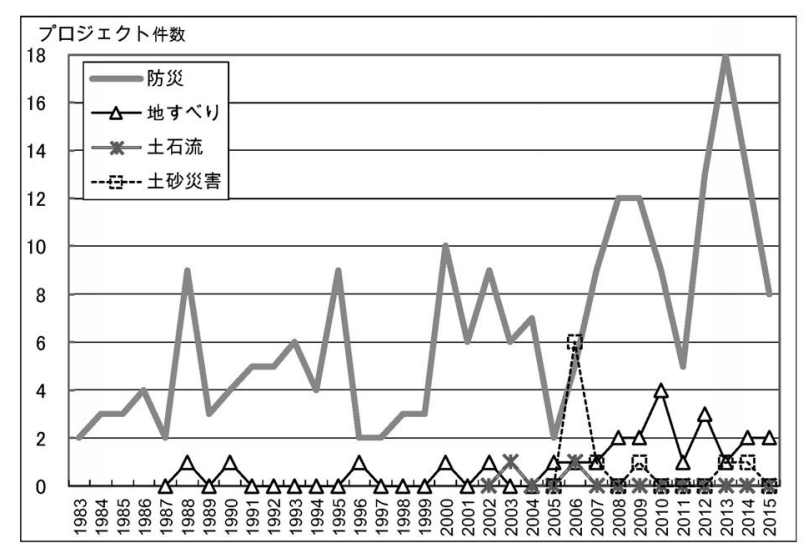

図一 1 斜面防災に係るプロジェクト数1)を一部修正 当該年で発行されるJICAプロジェクト報告書のうち表題に 「防災」「地すべり」「土石流」「土砂災害」が含まれるものを 計上。

しかしながら，日本政府が開発途上国に対して実施し てきた地すべり対策事業では，現地政府がその工事の適 正な事業評価や費用対効果判定を実施できるまでに至っ ていないことが多い。事業評価や効果判定が害施できて いない最大の要因は，開発途上国においては判定や検証 を行うための十分かつ精度の高いデータが存在していな い，もしくは蓄積されていないことによるものである。 特にJICAが実施してきた地すべり対策事業の対象地域 の多くは極貧困地域であり, 違法居住者も多数いること から，現地のインフラ設備に係る正確なデータはもちろ ん，保全対象者数などの最も基本的なデータさえも取得 できていないことが多々ある。またこのような地域は概 して治安が極めて悪く, 日本人や現地政府職員が, デー 夕取得のために追加調查を実施することは容易ではない。 例えデータがあった場合においても，精度の高い事業評 
価を実施するためには膨大なデー夕を収集・整理・分析 する必要があり，極めて限られた人員・予算で，災害復 旧や住民対応等の日常業務をこなしていかなければなら ない現地政府職員にとっては，このような膨大なデー夕 を使用した事業評価は煩雑な作業として捉えられ，援助 プロジェクト終了後には形骸化され，全く利用されなく なってしまうことが大いに予想される。

このような背景のもと，開発途上国における地すべり 対策事業の事業評価を，限られたデー夕で簡便に，かつ 多忙な現地政府職員に受け入れられる分かり易い手法で 実施できるようにすることが急務であると著者は考えた。

本報告は，JICAが2012〜2015年に実施した開発計画 調查型技術協力「モーリシャス共和国海岸保全・再生に 関する能力向上プロジェクト及び地すべり対策プロジェ クト」のうち「地すべり対策プロジェクト」(以下，本プ ロジェクト）に抒ける表面排水工・水平ボーリング工等 の地すべり抑制工事の事業評価を，妥当性・有効性・イ ンパクト・効率性・持続性の観点から, 事前評価・中間 評価・事後評価の 3 段階で実施した事例を紹介する。

\section{2. 事業評価方法の提案}

地すべり対策工事では，施工後に一定期間モニタリン グし地下水の低下や伸縮・ひずみ量の低減をもってその 効果を技術的に検証することが一般的である。これら技 術的な概成判断に加えて，本報告で対象としているよう な国際協力事業としての地すべり対策工事では，開発援 助の観点からの事業評価も必要となってくる。

\section{1 開発援助の事業評価}

開発援助に扔ける事業評価については，援助内容の改 善とアカウンタビリティの向上を目的として，経済協力 開発機構開発援助委員会（以下，OECD-DAC：Organisation for Economic Co-operation and Development, Development Assistance Committee）が「開発援助に おける評価原則」として「妥当性」「有効性」「インパクト」 「効率性」「自立発展性」という 5 つの評価項目を提唱し ている ${ }^{9)}$ 。この評価 5 項目は, 多くの国際協力機関によ り, 基本的な評価基準として採用されており, JICAも 本原則を評価手法の一つとして採用し，事業の段階ごと に事前評価，中間評価，事後評価等を実施することを推 奨している ${ }^{6}$ 。表 - 1 に評価 5 項目による評価の視点を 示すとともに，表- 2 に各段階における評価の目的の違 いについて記載する。

事前評価㧍よび事後評価では，評価 5 項目すべてにつ いて検証することを原則としているが，中間評価では妥 当性, 有効性, 効率性の 3 項目からその事業をモニタリ ングする6)。すなわち事業の途中段階において，その害 績や課題から，妥当性を再検証するとともに，有効性・ 効率性の観点から目標達成見込み，事業の促進・阻害要 因とその動向等を分析することとなる。

\section{表一 1 DAC評価 5 項目による評価の視点 ${ }^{6)}$}

\begin{tabular}{|c|c|}
\hline 項目 & 視点 \\
\hline $\begin{array}{l}\text { 妥当性 } \\
\text { relevance }\end{array}$ & $\begin{array}{l}\text { 開発援助と,ターゲットグループ・相手国・ドナ } \\
\text { 一の優先度並びに政策・方針との整合性の度 } \\
\text { 合い。 }\end{array}$ \\
\hline $\begin{array}{l}\text { 有効性 } \\
\text { effectiveness }\end{array}$ & 開発援助の目標の達成度合いを測る尺度。 \\
\hline $\begin{array}{l}\text { 効率性 } \\
\text { efficiency }\end{array}$ & $\begin{array}{l}\text { インプットに対するアウトプット(定性ならびに定 } \\
\text { 量的)を計測する。開発援助が期待される結果 } \\
\text { を達成ためにコストのかからない資源を使って } \\
\text { いることを示す経済用語。 }\end{array}$ \\
\hline $\begin{array}{l}\text { インパクト } \\
\text { impact }\end{array}$ & $\begin{array}{l}\text { 開発援助によって直接または間接的に, 意図 } \\
\text { 的または意図せずに生じる, 正・負の変化。開 } \\
\text { 発援助が, 地域社会・経済・環境ならびにその } \\
\text { 他の開発の指標にもたらす主要な影響や効果 } \\
\text { を含む。 }\end{array}$ \\
\hline $\begin{array}{l}\text { 持続性 } \\
\text { sustainability }\end{array}$ & $\begin{array}{l}\text { ドナーによる支援が終了しても，開発援助によ } \\
\text { る便益が継続するかを測る。開発援助は, 環境 } \\
\text { 面でも財政面でも持続可能でなければならな } \\
\text { い。 }\end{array}$ \\
\hline
\end{tabular}

表一2 評価段階ごとの目的の違( ${ }^{6)}$

\begin{tabular}{|c|c|}
\hline 時期 & 目的 \\
\hline 事前評価 & $\begin{array}{l}\text { 事業の必要性や効果, 実施計画等を確認する。ま } \\
\text { た, 成果目標を設定し, 今後の評価計画を明確に } \\
\text { する。 }\end{array}$ \\
\hline 中間評価 & $\begin{array}{l}\text { 事業が順調に効果発現に向けて実施されているか } \\
\text { を検証し, 評価対象事業の計画見直しや運営体制 } \\
\text { の改善に資する。 }\end{array}$ \\
\hline 事後評価 & $\begin{array}{l}\text { より一層の効果的効率的な実施および十分な説明 } \\
\text { 責任を果たすことを目的として実施する。 }\end{array}$ \\
\hline
\end{tabular}

\section{2 地すべり対策工事に特化した事業評価}

国際協力事業としての地すべり対策工事についても， 技術的概成の確認に加えて, 開発援助の観点から検証す る必要があり，ここでは前節で述べたOECD-DACの評 価 5 項目を用いて，事前，実施中，事後の 3 段階で事業 評価を行うことが望ましいと考えた。以下に各段階にお いて地すべり対策工事で評価すべき具体的ポイントを提 案し整理する。

\subsection{1 事前評価の評価ポイント}

事前評価では，地すべり対策工事の必要性や効果，実 施計画等を確認する必要があり，評価 5 項目の考え方を 用いつつ外部要因やリスクを整理し，成果目標を明確に することが重要となる。

表一 1 に示した通り，妥当性とは援助される相手国側 の要望との整合性として考えることができ，それは相手 国側の地すべり対策に係る政策や法令，要望，防災意識 などと比較検討することで検証できると考えた。有効性 とは地すべり対策工事を実施することで対象地域の地す ベり被害軽減を予測できるかどうかであり，その点につ いて言及した。効率性とは地すべり対策工事の場合，い わゆる費用対効果のことであり，定量的評価ポイントの 一つとなる。ただし多くの開発途上国では費用対効果を 算出するためのデー夕を取りそろえること自体が困難で あることが多く，入手し得るデー夕を用いて，より簡便 で分かりやすい手法を国ごとに提案していくことが重要 
である。インパクトとは移転した地すべり対策技術が相 手国内や域内で普及可能か，応用可能かを検証すること であり，合わせて，周辺の生活環境や森林保全に悪影響 がないかを確認することと判断した。持続性とはプロ ジェクト終了後，地すべり対策を政策面・財政面・技術 面で継続して実施していけるかを想定することとした。

これらを踏まえて項目ごとに，著者が考えた評価すべ きポイントを表ー 3 に整理する。

\subsection{2 中間評価の評価ポイント}

中間評価は，地すべり対策工事の途中段階において， 事業が順調に効果発現に向けて実施されているかを検証 し，評価対象事業の計画見直しや運営体制の改善に資す るもので，妥当性・有効性・効率性について検証する。 なお，中間評価時における有効性とは，当初想定した事 業効果が発現するかという点であり，本プロジェクトの 地すべり対策工事では，その目的から，地下水上昇や地 表水溢水が抑制されているかが該当すると考えた。

これらを踏まえて項目ごとに，著者が考えた評価すべ きポイントを表ー 4 に整理する。

\subsection{3 事後評価の評価ポイント}

事後評価は，地すべり対策工事の終了後において，よ り効果的かつ効率的な事業実施および十分な説明責任を 果たすことを目指すために実施するもので，評価 5 項目 について検証する。

事前評価の妥当性の項目において評価した相手国側の

\section{表ー 3 地すべり対策工事における事前評価ポイント}

\begin{tabular}{|c|c|}
\hline 項目 & 評価ポイント \\
\hline 妥当性 & $\begin{array}{l}\text { ·相手国の政策との整合性 } \\
\cdot \text { 地すべりに係る法令・条例・規制の有無 } \\
\text { ·地すべり防止区域等の土地利用規制の有無 } \\
\text { ·保全対象地域内での重要公共構造物の有無 } \\
\text { ·相手国や詨象地域のニーズとの整合性 } \\
\text { •地元の防災意識·事業への要望 }\end{array}$ \\
\hline 有効性 & $\begin{array}{l}\text { ·目標と成果の因果関係の適切性 } \\
\text { •他の事業との相乗効果 }\end{array}$ \\
\hline 効率性 & ·費用対効果·便益 \\
\hline インパクト & $\begin{array}{l}\text { •他地域への適用性(応用可能かどうか) } \\
\text { •国内での普及・向上 } \\
\text { •良好な環境形成·保全への適合性 }\end{array}$ \\
\hline 持続性 & $\begin{array}{l}\text { ·政策: 促進されるための政策・制度の保持 } \\
\text { ·財政:予算の確保 } \\
\text { •技術:対象者の技術力の高さ } \\
\text { •地域での協力体制 }\end{array}$ \\
\hline
\end{tabular}

\section{表ー4＼cjkstart地すべり対策工事における中間評価ポイント}

\begin{tabular}{|c|c|}
\hline 項目 & 評価ポイント \\
\hline 妥当性 & $\begin{array}{l}\text { ·当該事業の進捗状況 (当初計画どおりか, 進捗率) } \\
\text { •関連事業の進捗状況 (当初計画どおりか, 進捗率) } \\
\text { ·社会経済情勢の変化 (保全対象の増減など) } \\
\text { ·保全対象者の意向 (ニーズ)の変化 }\end{array}$ \\
\hline 有効性 & $\begin{array}{l}\text { •事業効果の発現状況 (地下水上昇の抑制, 地表水 } \\
\text { の溢水抑制など) }\end{array}$ \\
\hline 効率性 & $\begin{array}{l}\text { •コスト縮減代替案 (集中投資による施工量増による } \\
\text { コスト縮減など)の必要性 } \\
\text { •対策工法代替案の必要性 } \\
\text { •スケジュール見直しの必要性 }\end{array}$ \\
\hline
\end{tabular}

政策や法令，要望，防災意識は，数年単位で大きく変更 されることはないと考え，事後評価における妥当性とは 地すべり対策工事の進渉度や実施機関・対象地域住民の 満足度で検証されると考えた。効率性は計画した予算で 十分な地すべり抑制・抑止効果が現れたかどうかを判断 した。また有効性，インパクト，持続性については，事 前評価で想定した評価ポイントを終了後に確認すること とした。

これらを踏まえて項目ごとに，著者が考えた評価すべ きポイントを表ー 5 に整理する。

\subsection{4 評価シートの提案}

事業評価を実施するにあたっては，前述した評価ポイ ントの結果をチェック・記述するための簡便な評価シー トを各段階で作成した。評価シートでは評価ポイントに 該当する項目を選択しチェックすると同時に，定性的評 価を記述する欄を設けた。また評価ポイントやチェック 項目は多くなりすぎず，要点が整理されたものとなるよ うに心がけた。

\section{3. 事業評価の実施}

提案した事業評価手法に基づいて，本プロジェクトの 地すべり対策工事に対して 3 段階の事業評価を実施した。 評価は著者を含む日本人専門家 3 名程度と, モーリシャ スにおける地すべり対策の実施機関である公共インフ ラ・陸上交通省（以下，MPI：Ministry of Public Infrastructure and Land Transport) 職員 8 名程度で協議し ながら決定した。評価のうち整合性や相乗効果，応用適 用性などチェック項目の多くは 4 段階評価（高い，やや 高い，やや低い，低い）を用いているが，その判断基準 は主観的な技術者判断によった。厳密にいえば，評価基 準として，必要となる事象を設定するほか，関係者に対 してアンケート調査等を実施するべきではあったが， モーリシャス政府が主体的に実施する初めての地すべり 対策工事において，事業評価の概念と実施方法を，限ら れた期間内に理解してもらう目的で試験的に実施したた

表一 5 地すべり対策工事における事後評価ポイント

\begin{tabular}{|c|c|}
\hline 項目 & 評価ポイント \\
\hline 妥当性 & $\begin{array}{l}\cdot \text { 当該事業の進捗状況 (当初計画ど掞りだったか) } \\
\cdot \text { •関連事業の進捗状況 (当初計画どおりだったか) } \\
\text { •対策実施機関の満足度 } \\
\text { •対策実施地区 (地元)の満足度 }\end{array}$ \\
\hline 有効性 & $\begin{array}{l}\text { •目標と成果の因果関係の適切性(成果の達成が } \\
\text { 標達成に繋がったか) } \\
\text { •他の事業との相乗効果 }\end{array}$ \\
\hline 効率性 & $\begin{array}{l}\text { •費用に対する事業効果の発現状況（当初予算で } \\
\text { 地すべり抑制・抑止できたか) }\end{array}$ \\
\hline インパクト & $\begin{array}{l}\text { •他地域への適用性 (応用可能かどうか) } \\
\text { •国内での普及・向上 } \\
\text { •良好な環境形成・保全への適合性 }\end{array}$ \\
\hline 持続性 & $\begin{array}{l}\text { •政策: 促進されるための政策・制度の保持 } \\
\text { ·財政:予算の確保 } \\
\text { •技術:対象者の技術力の高さ } \\
\text { •地域での協力体制 }\end{array}$ \\
\hline
\end{tabular}


め，本事業評価手法では技術者判断のみで評価した。将 来的には同国において地すべり対策工事に係る事業評価 のための基準を設定していく必要がある。

事業評価を開始するにあたり，本プロジェクトで対象 とした地すべりとその対策工事を以下に概説する。

\section{1 対象地すべりと対策工事の概要}

対象とする地すべりは，首都ポートルイス市郊外の Chitrakoot地区（図－2）に拈いて活動している地すべ りで，家屋被害が10世帯以上あり，MPIからの調査・対 策の要請があった地区である。

空中写真判読および現地踏査からChitrakoot地区では 多くの地すべり地形が認められたが，ボーリング調查， モニタリング（地表伸縮計，孔内傾斜計，パイプひずみ 計，地下水位計，雨量計）, 物理探査（弾性波探査，電 気探査）から，特に活動的な地すべりブロックとして， AブロックとBブロックが確認され（図－3），他の地す ベりブロックは現在ではほぼ活動を停止しているか，現 状では不活発と判断された ${ }^{10}$ 。

Aブロックは長さ $300 \mathrm{~m}$, 幅 $150 \mathrm{~m}$ 程度で，学校のほか 民家も多く密集している。Aブロック内の学校抢よび学 校周辺の民家では，構造物にクラックが発生しているほ か，孔内傾斜計で深度 $7 \mathrm{~m}$ のすべり面が確認されている。 地質断面図（図－4）に示すように深度 $7 〜 10 \mathrm{~m}$ 以深に 玄武岩または玄武岩質角砂岩が分布し，最上部 $2 \sim 5 \mathrm{~m}$ 程度は風化している。岩盤を覆って崩積土が分布する。

Bブロックは長さ $100 \mathrm{~m} ，$ 幅 $200 \mathrm{~m}$ 程度であり，民家 3

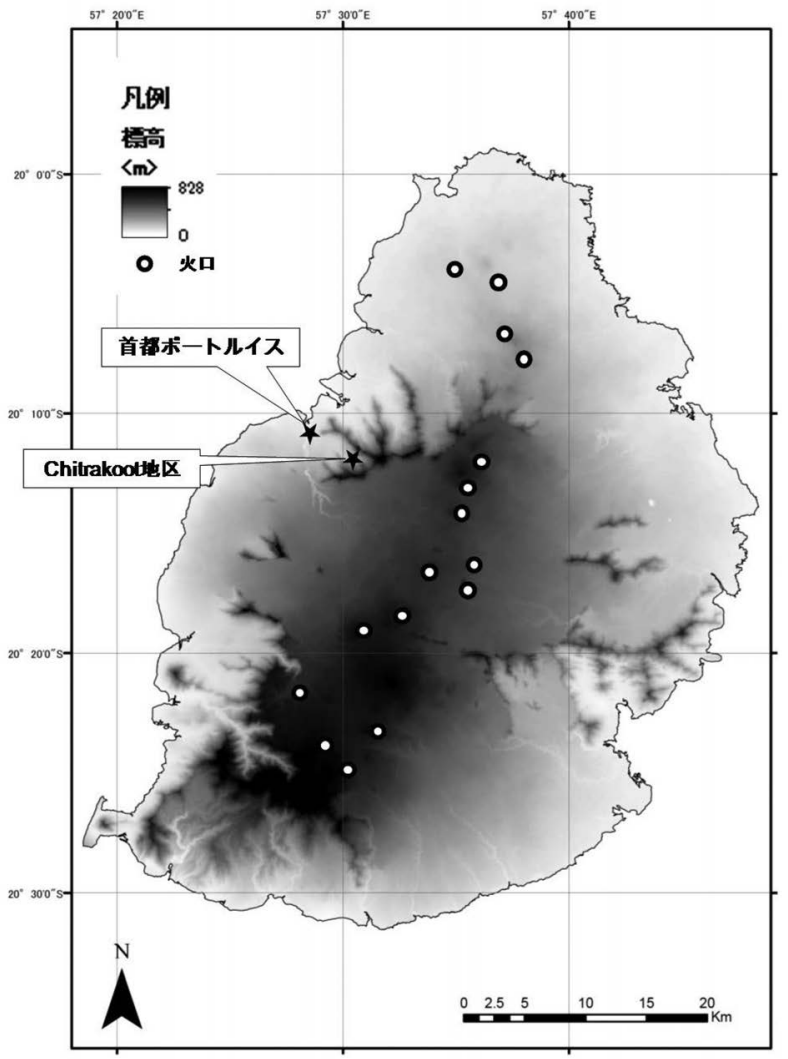

図一2 モーリシャス色別標高図

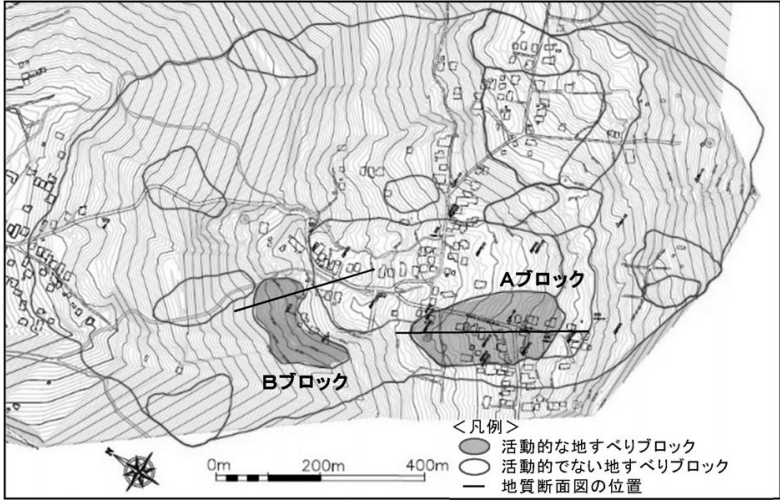

图ー3 Chitrakoot地区の地すべりブロック ${ }^{10} を 一$ 部修正

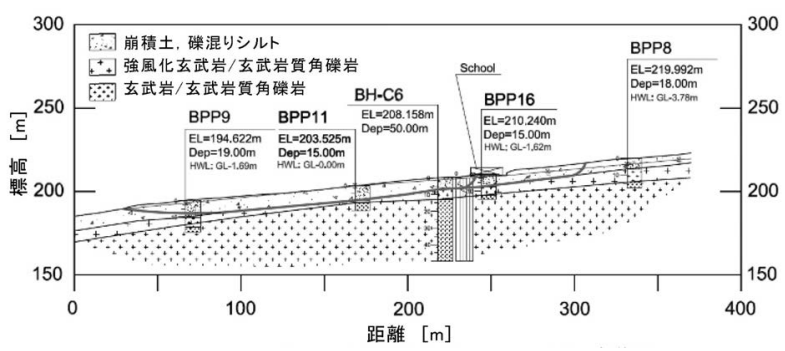

図ー4 Aブロック地質断面図 ${ }^{10}$ を一部修正

世帯が存在し，民家にクラックなどの変状がみられる。 地質断面図（図－5）に示すように深度10m以媣に玄武 岩または玄武岩質角䃇岩が分布し，最上部 $1 \sim 2 \mathrm{~m}$ 程度 は風化している。岩盤を覆って崩積土が分布する。

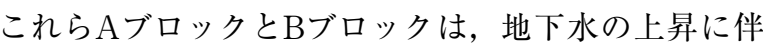
い活動する再活動型地すべりであったため，地下水の上 昇を抑制する抑制工が最も有効な対策であると判断し， 地下水上昇を招く地表水の排水施設，表層の地下水の排 除施設の整備を行った ${ }^{2)}$ 。対策工計画の概要を表 $-6,7$ に 示す。

なおAブロックおよびBブロックにおけるこれらの地 すべり対策工事は，Aブロックのうち用地買収を要しな い地区を「工区 $1 」$ ，用地買収を要する地区を「工区 $2 」$, Bブロックを「工区 3 」として工区 1 から順次施工を実 施することとした。本プロジェクトでは工区 1 が2015年 までに完工し，工区 2 およ゙゙工区 3 についてはモーリ シャスMPIが独自予算で2016年以降に対策工事を順次実 施中である。

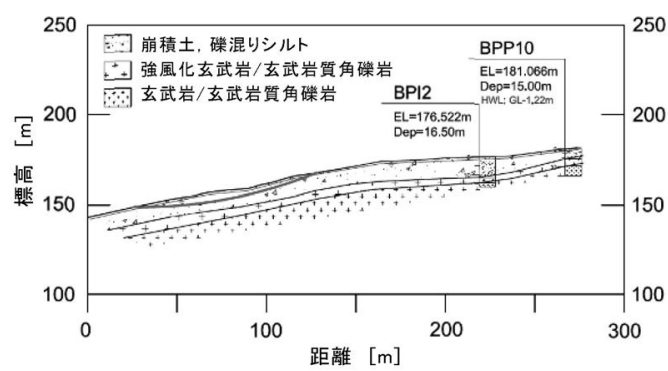

図ー5 Bブロック地質断面図 ${ }^{10}$ を一部修正 
表一 6 Aブロック地すべり対策エ一覧 ${ }^{2)}$

\begin{tabular}{|c|c|c|c|}
\hline \multicolumn{2}{|l|}{ 工種 } & 数量 & 備考 \\
\hline \multirow{2}{*}{$\begin{array}{l}\text { 洪水用大断面水 } \\
\text { 路 }\end{array}$} & $\mathrm{CH}-1$ & $\mathrm{~L}=215 \mathrm{~m}$ & \\
\hline & $\mathrm{CH}-2$ & $\mathrm{~L}=130 \mathrm{~m}$ & \\
\hline \multirow{3}{*}{ 水平ボーリング工 } & HD-1 & $\mathrm{L}=250 \mathrm{~m}$ & $50 \mathrm{~m} \times 5$ \\
\hline & HD-2 & $\mathrm{L}=210 \mathrm{~m}$ & $50 \mathrm{~m} \times 3,30 \mathrm{~m} \times 2$ \\
\hline & HD-3 & $\mathrm{L}=350 \mathrm{~m}$ & $50 \mathrm{~m} \times 7$ \\
\hline \multirow{2}{*}{ 明暗渠工 } & $\mathrm{OB}-1$ & $\mathrm{~L}=55 \mathrm{~m}$ & \\
\hline & OB-2 & $\mathrm{L}=85 \mathrm{~m}$ & \\
\hline 表面排水路工 & SD-1 & $\mathrm{L}=75 \mathrm{~m}$ & \\
\hline \multirow{3}{*}{ 暗渠工 } & BD-1 & $\mathrm{L}=35 \mathrm{~m}$ & $\Phi 200 \times 1$ \\
\hline & BD-2 & $\mathrm{L}=32 \mathrm{~m}$ & $\Phi 200 \times 3$ \\
\hline & BD-3 & $\mathrm{L}=40 \mathrm{~m}$ & $\Phi 200 \times 1$ \\
\hline \multirow{5}{*}{$\begin{array}{l}\text { 既存水 路 改修工 } \\
\text { (拡幅・護岸) }\end{array}$} & UD-1 & $\mathrm{L}=5 \mathrm{~m}$ & 拡幅·護岸 \\
\hline & UD-2 & $\mathrm{L}=10 \mathrm{~m}$ & 拡幅·護岸 \\
\hline & UD-3 & $\mathrm{L}=47 \mathrm{~m}$ & 拡幅·護岸 \\
\hline & RUD-1 & $\mathrm{L}=175 \mathrm{~m}$ & 水路拡幅・水路補強 \\
\hline & RUD-2 & $\mathrm{L}=55 \mathrm{~m}$ & 拡幅·護岸, 落差工 \\
\hline \multirow{3}{*}{ 付帯工 } & 橋梁 & 2 & 歩行者用 \\
\hline & 橋梁 & 5 & 車両用 \\
\hline & 集水柝 & 3 & \\
\hline
\end{tabular}

表ー 7 Bブロック地すべり対策エ一覧 ${ }^{2)}$

\begin{tabular}{llll}
\hline \multicolumn{1}{c}{ 工種 } & & 数量 & 備考 \\
\hline \multirow{3}{*}{ 水平ボーリング工 } & $\mathrm{HD}-4$ & $\mathrm{~L}=250 \mathrm{~m}$ & $50 \mathrm{~m} \times 5$ \\
& $\mathrm{HD}-5$ & $\mathrm{~L}=250 \mathrm{~m}$ & $50 \mathrm{~m} \times 5$ \\
& $\mathrm{HD}-6$ & $\mathrm{~L}=250 \mathrm{~m}$ & $50 \mathrm{~m} \times 5$ \\
表面排水路工 & $\mathrm{SD}-2$ & $\mathrm{~L}=300 \mathrm{~m}$ & \\
\hline
\end{tabular}

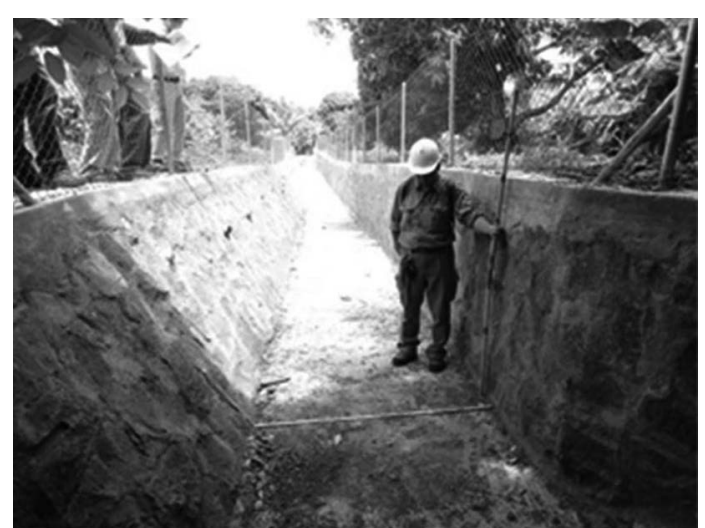

写真－1 洪水用大断面水路

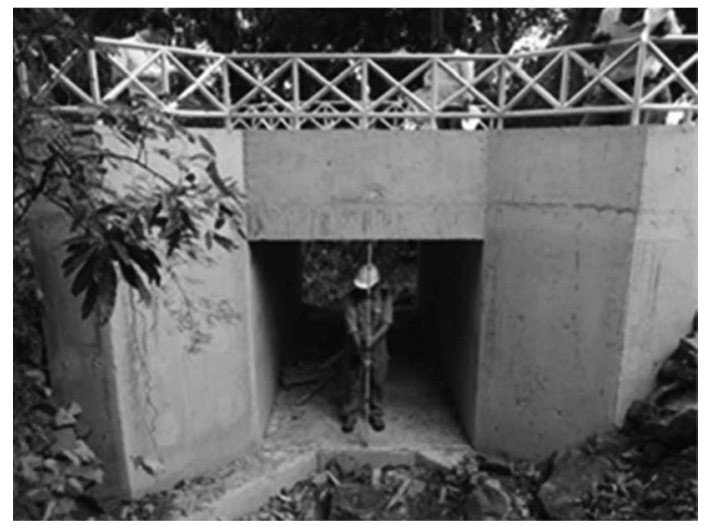

写真－２＼cjkstart既存水路改修工（拡幅・護岸）

地すべり対策工事の事業評価における事後評価は，工 区 1 〜 のすべての対策工事が完了した後に実施するこ とが望ましいが，地すべり対策工事の事業評価方法を提
案すること，さらにその方法をモーリシャスに技術移転 することを目的として，工区 1 が完了した時点で事後評 価までを試験的に実施した。今後すべての地すべり対策 工事が完了した後，本提案手法を用いて全体の事業評価 が実施されることを期待する。

\section{2 事前評価}

事前評価は，地すべり対策工事（2014年 7 月～2014年 12月）を計画していた2013年11月頃に実施した。評価ポ イントは表- 3 のとおりであり，そのポイントごとに チェック並びに定性的評価を行った。効率性の評価にお いては費用対効果を算出し，定量的評価を行った。以下 に費用対効果の算出法について概説する。

本プロジェクトが開始される以前のモーリシャスでは, 地すべり対策とは地すべり活動中のその土地を捨てて， 集落全体が安定している地区に移転することであった。 移転先における土地および住居は，住民負担ではなく モーリシャス政府が負担し，住民に提供されていた。そ のため，ここでは対象地域の集落が移転する場合に政府 が必要とする費用と，本プロジェクトの地すべり対策工 事で計画している工事費用を比較し，工事費用が移転費 用を下回れば費用対効果は十分に高いと判断することと した。

対象地域において移転が必要な世帯数は21世帯である。 すでに地すべり被害が顕著で住民移転が計画されている 他の地区では，政府が住民の移転用に準備した不動産は 1 世帯あたりで，土地面積 $440 \mathrm{~m}^{2}$, 家屋（2階建て）延 床面積 $110 \mathrm{~m}^{2}$ であることから，対象地域 1 世帯あたりに 提供される不動産として本值を採用した。MPIへの聞き 取り調査から，同国では土地や建物の不動産価值を算出 するにあたり概略単価として，土地：100,000ルピー

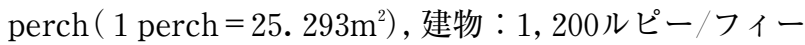
$ト^{2}\left(1\right.$ フィート $\left.{ }^{2}=0.093 \mathrm{~m}^{2}\right)$ を一般的に使用するとの ことであった。そのため，これら概略単価に土地面積440 $\mathrm{m}^{2}$ と家屋の延床面積 $110 \mathrm{~m}^{2}$ をそれぞれ乗じて, 1 世帯あた りの移転費用を $3,158,967$ ルピー（約 960 万円）として算 出した。これが21世帯であることから総移転費用は $66,338,307$ ルピー（約 2 億円）と算出され，対策工費 29,500,400ルピー（約 9, 100万円）を大きく上回った。 そのため費用対効果は高いと判断した。

費用対効果を算出した効率性を含め，事前評価を評価 シート（図－6）にまとめた。

\section{2 中間評価}

中間評価は地すべり対策工事の工区 1 における工事実 施中の2014年10月頃に実施した。評価ポイントは表 - 4 のとおりであり，そのポイントごとにチェック並びに定 性的評価を行った。なお，妥当性における「関連事業の 進渉状況」については，関連事業が当該期間内に実施さ れなかったことから，評価シートから削除した。中間評 価の評価シートを図 -7 に示す。 


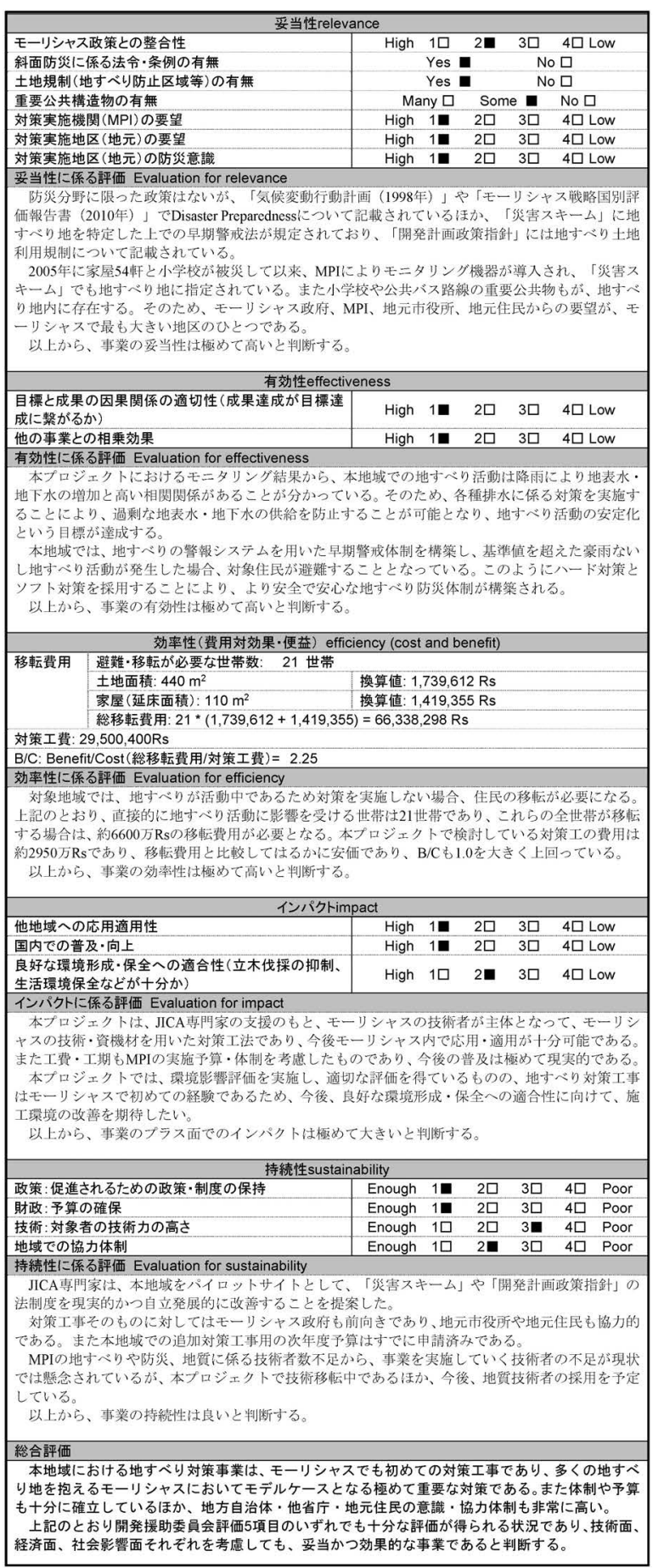

図ー6＼cjkstart地すべり対策工事の事前評価シート

\section{3 事後評価}

事後評価は地すべり対策工事の工区 1 が完工した2015 年 1 月頃に実施した。評価ポイントは表- 5 のとおりで あり，そのポイントごとにチェック並びに定性的評価を 行った。先にも述べた通り，事後評価は工区 2 押よび工 区 3 を含むすべての対策工事が完了した後に実施するこ とが望ましいが，ここでは事業評価手法の技術移転を目 的とし，工区 1 完工後に試験的に評価を実施した。事後 評価の評価シートを図 -8 に示す。

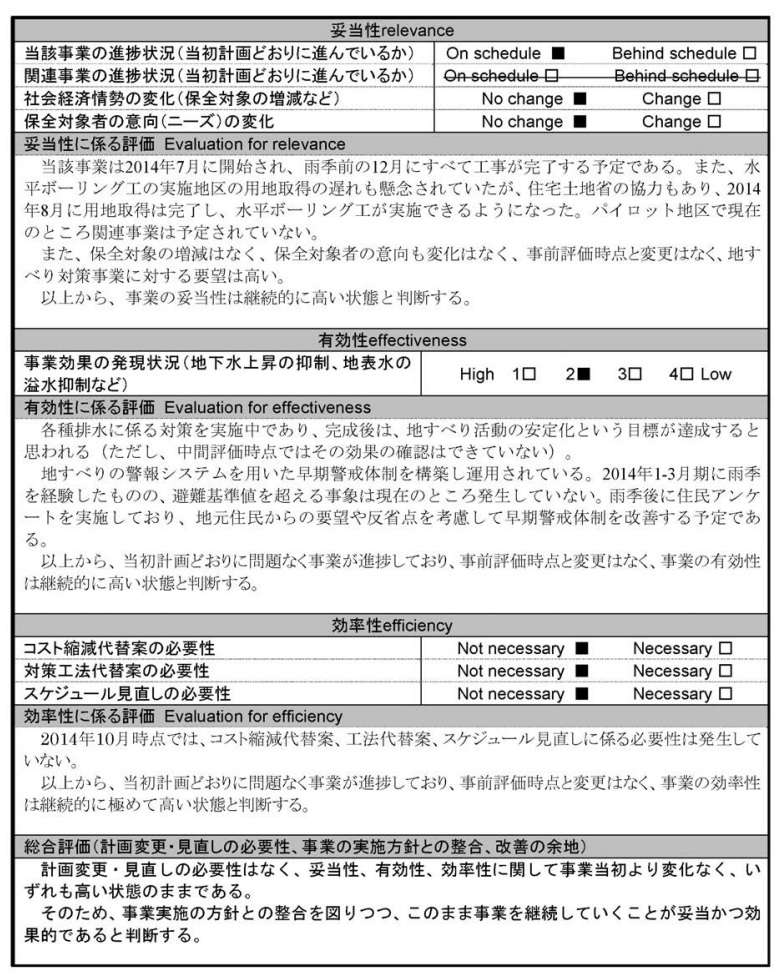

図－７地すべり対策工事の中間評価評価シート

\section{4. おわりに}

今回, 日本の国際協力事業で実施した地すべり対策工 事に打いて, 妥当性・有効性・インパクト・効率性・持 続性の観点から, 事前評価・中間評価・事後評価の 3 段 階で事業評価を試験的に行った。これはJICA等の国際 協力機関が利用しているOECD-DAC評価 5 項目を用い た評価手法を，現地政府職員の使い勝手を考慮して，さ らに地すべり対策工事特有の事象等を踏まえてアレンジ したものである。

本手法は地すべり対策工事の国際協力事業において適 用可能であり，日本が技術移転した地すべり対策工事を 客観的に評価する上で利用されることが望まれる。ただ し, 援助内容の改善とアカウンタビリティの向上を目的 に，その国に応じた評価基準を設ける，アンケート調查 等を利用したデー夕収集・整理方法を確立するなど，事 業評価手法を日々改善していくことが必要不可欠である。 事業評価手法の改善は，国際協力事業に扔ける日本から の地すべり対策技術のより良い普及・移転に今後，大き く貢献するものを考える。

\section{謝 辞}

本提案を検討するにあたり, 国際航業株式会社岩崎智 治博士, 坂井友里江氏, OYOインターナショナル株式 会社横尾文彦氏, 原崇氏とは, 提案をまとめていく過程 で有意義な議論を複数回に渡り実施した。国際航業株式 会社脇田エミリオ和林氏には図作成を支援いただいた。 ここに記して上記の皆様に感謝いたします。

本活動はJICAが実施した開発計画調查型技術協力 
当該事業の進捗状況 (当初計画どおりに性relevance

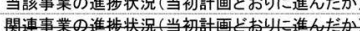
坟策実施機関(MPI)の满足度 対策実施地区(地元) 满足度 妥当性に係る評価 Evaluation for relevance 当陔事業俚予定どわり

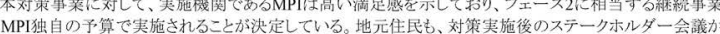
高い满足感寺している

以上から、事亲の妥当性は極めて高いと判断する。

\section{有効性effectiveness}

\begin{tabular}{l|lllll} 
目標と成果の因果関係の適切性(成果達成が目標達成 & High & 1 口 & $2 \square$ & $3 \square$ & $4 \square$ Low \\
l集がったか)
\end{tabular} \begin{tabular}{l|lllll} 
に熬がったが & High & $1 \square$ & $2 \square$ & $3 \square$ & $4 \square$ Low \\
他の事業との相乗勃果 & High & $1 \square$ & $2 \square$ & $3 \square$ & $4 \square$ Low
\end{tabular} 有効性に二係る倸価 Evaluation for effectiveness

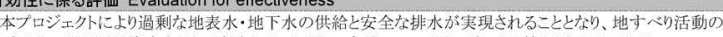
灾定化といら目標が達成すると予想される。ただし、今後のたニ舛ングによる娭証が必要である

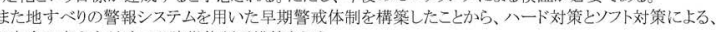

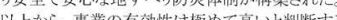

\begin{tabular}{|l|lllll}
\hline \multicolumn{8}{c}{ 効率性efficiency } \\
\hline 費用に対する事業效果の発現状況 (当初予算で地すべ & High & 10 & 2 口 & $3 \square$ & 4口 Low
\end{tabular}

抑制・抑止できたが

効率性に係る評価 Evaluation for efficienc

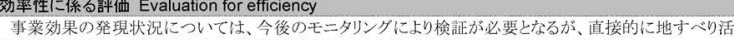

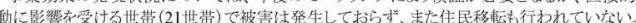

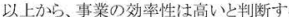

\begin{tabular}{|c|c|c|c|c|c|}
\hline & \multicolumn{2}{|c|}{ High 1 . } & & & \\
\hline & High & 1 & & & \\
\hline $\begin{array}{l}\text { 他地域への応用適用性 } \\
\text { 国内での普及・向上 } \\
\text { 艮好な環境形成・保全への適合性(立木伐採の抑制、生 } \\
\text { 活環境保全などが分か） }\end{array}$ & High & & & 3ם & \\
\hline
\end{tabular}

活環境保全などが十分か)

ンパクトに係る評価 Evaluation for impact

本フロシェェ外はモーリシャスでも適用可能な表面排水工と地下排水工を主体とした対策工事であり MPIとの共同の施工監理により、地元業者が施工した。をのため今後の応用適用性ならびに国内での音

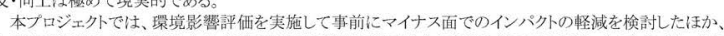
水路に落下防止相を設置したり、通行用橋梁を追加で建設したりするなどの対応を行ったことにより、良好

以上から、事業のプラス面でのインバタは極めて高いと判断する。

\begin{tabular}{|c|c|c|c|c|c|c|}
\hline \multicolumn{7}{|c|}{ 持続性sustainability } \\
\hline 政策: 促進されるための政策·制度の保持 & Enough & $1 \square$ & $2 \square$ & $3 \square$ & $4 \square$ & \\
\hline 財政:予算の確保 & Enough & 1 ! & $2 \square$ & $3 \square$ & 4D & Poor \\
\hline 技術:対象者の技術力の高さ & Enough & $1 \square$ & $2 \square$ & $3 \square$ & $4 \square$ & \\
\hline 地域で協力体制 & Enough & $1 \Pi$ & $2 \square$ & $3 \square$ & 4ロ & Poor \\
\hline
\end{tabular}

地域での協力体制

2П $3 \square \quad 40$ Poor

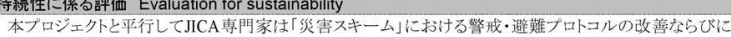

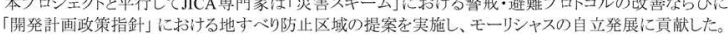

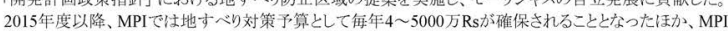

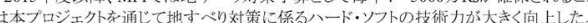

またチトラクート地区やポートルイス市役所においても地すへり対策の重要性・必要性が大きく認識きれ

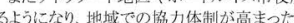

以上から、事業の持続性は極め大高いと判断する。

総合評価 Overall evaluation

本地域における地すべり対策事業は、モーリシャスでも初めての対策エ事であったが、MPIのほ かMHLやポートルイス市役所、林野局、水道局等の関係機関、ならびに地元住民の積極的協力か ら、予定どおりのスケジュール・予算で完了した。また次年度以降もMPIでの予算や実施体制が碓 保されており、国内での技術普及も大きく期待できる。ただし、対策効果の発現に当たっては今後 のモニタリングが必要となる。

上記のとおり開発援助委員会評価5項目のいずれでも極めて高い評価が得られる状況であり、技 術面、経済面、社会影響面それぞれを考慮しても、妥当かつ効果的な事業であったと判断する。

図－8＼cjkstart地すべり対策工事の事後評価シート
「モーリシャス共和国海岸保全・再生に関する能力向上 プロジェクト及び地すべり対策プロジェクト」のうち， 「地すべり対策プロジェクト」の一環で実施したもので あり，著者に貴重な機会をいただいたことに感謝します。 本活動を実施するにあたりモーリシャス共和国で苦楽 を共にした公共インフラ・陸上交通省の関係諸氏に対し て，深謝いたします。

\section{引用文献}

1）桑野健・市川建介・塚本哲・中川淳史（2011）：エチオピア国 アバイ溪谷地すべりに対する日本の斜面災害調査・解析技術 の貢献, 日本応用地質学会研究発表会講演論文集 2011, pp. 141 -142 .

2 ）独立行政法人国際協力機構（2015）：モーリシャス国地すべり 対策プロジェクト，ファイナル・レポート，pp. 6.1-6.30.

3 ) 石坂隆・鈴木吉春・宇津木慎司 (2015) : 集水井を利用した地 すべり対策工事の海外技術移転とその成果についてーホン ジュラス首都圈地すべり対策工事の例 - ，日本地すべり学会 誌, Vol. 52, No. 4, pp. 174-179.

4 ）榎田充哉・塚本哲・市川建介・市川裕一（2015）：エチオピア 国に㧍ける地すべり対策技術移転と課題，日本地すべり学会 誌, Vol. 52, No. 4, pp. 180-184.

5 ）田内宏明・森幹尋（2015）：ネパールSinduli Roadに抢ける斜 面対策工事事例，日本地すべり学会誌，Vol. 52,No. 4, pp. 168 $-173$.

6 ）独立行政法人国際協力機構評価部（2010）：新JICA事業評価 ガイドライン, pp. 2-20.

7 ）国土交通省（2008）：公共事業評価の費用便益分析に関する技 術指針, 3p.

8 ）国土交通省水管理・国土保全局砂防部（2012）：地すべり対策 事業の費用便益分析マニュアル (案)，pp. i - ii .

9 ）独立行政法人国際協力機構（2012）：DAC評価 5 項目の評価 視点及び判断基準の標準化報告書, pp. 4-18.

10）独立行政法人国際協力機構（2015）：モーリシャス国地すべり 対策プロジェクト，ファイナル・レポート，pp.4.1-4.8.

（原稿受付 2016 年12月 2 日，原稿受理2017年 9 月12日） 